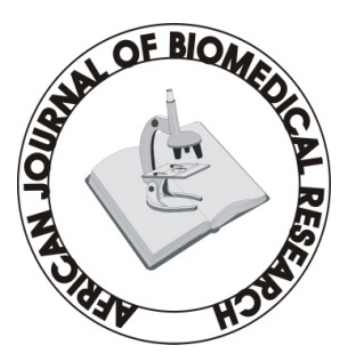

Full-text available at http://www.ajbrui.com http://www.bioline.br/md http://www.ajol.com

Received:

September 2007

Accepted (Revised): November 2007

Published

January 2008
Full Length Research Article

\section{Potential effects of nutrient supplement on the anthropometric profiles of HIV-positive patients: complementary medicine could have a role in the management of HIV/AIDS}

\author{
${ }^{1}$ Oguntibeju O.O, W.M.J van den Heever ${ }^{1} \&$ F.E Van Schalkwyk ${ }^{2}$
}

School of ${ }^{1}$ Health Technology $\&{ }^{2}$ Hospitality and Tourism, Central University of Technology,

Free State, Bloemfontein 9300, South Africa

\section{ABSTRACT}

This is a purposive open-ended study that consisted of a baseline, monthly and final measurements (at the end of nutrient supplementation) that lasted for six months. Anthropometric measurements (BMI, percentage fat, waist-to-hip ratio and lean body mass) were done at baseline, monthly and at the end of study (final measurement) using known standard methods. The Tlymphocytes subsets were determined using flow cytometer. Participants fulfilled certain criteria for inclusion in the study. At baseline, of the 35 patients recruited into the study, 32 (94.1\%) showed a fat percentage below normal range. Twenty-four of the patients (68.6\%) had body mass index (BMI) within normal range, while a greater percentage of the patients had a normal waist-to-hip ratio (WHR). Of the 28 patients that completed the study, $26(96.3 \%)$ reported a fat percentage of below 18.5\%. There was no significant difference $(\mathrm{P}>0.05)$ between the fat percentage at baseline and end of the study in the whole group. The results showed that 19 (67.9\%) of the 28 patients had a BMI within the normal range after nutrient intervention. There was a significant positive correlation between the BMI and fat percentage. At the end of the study, the $\mathrm{CD} 4^{+} \mathrm{T}$-cell count showed no positive correlation with any of the anthropometric indices. The supplement showed no significant effect on the anthropometrics. Further study with large sample size is recommended to confirm supplement effect on the anthropometric profiles. The short duration of the study probably limited the positive trend of the supplement on the anthropometric profiles.

(Afr. J. Biomed. Res. 11: 13 - 22)

Key Words: HIV-positive/AIDS patients, supplement, lean body mass, percentage body fat, waist-hip-ratio, $C D 4^{+}$T-cell count

*Address for Correspondence : Dr O.O Oguntibeju, School of Medicine, Spartan Health Sciences University, Vieux Fort, St Lucia. Tel: 0017584546128 Email: bejufemi@yahoo.co.uk

Abstracted by:

African Index Medicus (WHO), CAB Abstracts, Index Copernicus, Global Health Abstracts, Asian Science Index, Index

Veterinarius, Bioline International , African Journals online 


\section{INTRODUCTION}

Infection with the human immunodeficiency virus (HIV) has a devastating effect on the nutritional status of infected persons (Gorbach \& Knox, 1992; Oguntibeju et al., 2005a). It has been noted that weight loss, often profound in magnitude depending on the stage of the infection and associated infections, are known features of HIV infection (Gorbach \& Knox, 1992; Oguntibeju et al., 2005b). HIV-positive/AIDS patients may lose $30-50 \%$ of their body mass before progressing to AIDS (erbert, 1973; Kotler et al., 1989). According to different researchers, weight loss can be caused by five mechanisms, namely, inadequate food intake, reduced intestinal absorption, abnormal food utilization, increased excretion of nutrients and increased host requirements (Kotler et al., 1989; Grunfeld \& Feingold, 1992; Macallan, 1999). It is also agreed that weight loss contributes to the progression of HIV infection to AIDS (Chlebowski 1985; Dannhauser et al., 1999).

Malnutrition has been an endemic problem in Africa for decades and it is complicated by a combination of factors including the recent impact of HIV/AIDS (Piwoz \& Preble, 2000). HIV/AIDS and malnutrition is interrelated. Research suggests that malnutrition increases the progression of HIV infection and in turn HIV infection exacerbates malnutrition through its attack on the immune system and body composition (Fawzi \& Hunter, 1998; Friis \& Michaelsen, 1998; Oguntibeju et al., 2003).

Research has shown that in the early period of HIV infection, weight gain or maintenance might be achieved through nutrition intervention, and this has helped to reduce the consequences of wasting in people living with HIV/AIDS [Babamento \& Kotler, 1997; Dwyer, 1998; Cimoch, 1997; Niyongabo et al., 1997). In the developing world, where the majority of people living with HIV cannot afford antiretroviral therapy, good nutrition combined with mineral and vitamin supplementation could be a strategic alternative source of therapy. Nutritional intervention may help to strengthen the immune system and reduce the severity and impact of opportunistic infections in people living with HIV/AIDS (Raiten, 1990; Woznicki \& D’Alessandro, 1997).

Few studies (Dannhauser et al., 1999; Niyongabo et al., 1999) have examined the relationship between HIV infection and adult anthropometry in South Africa and elsewhere in Africa. However, none has examined the association between HIV infection, anthropometry and nutrient supplementation in adult male and female populations, hence the reason to examine the potential effect of nutrient supplementation on anthropometric profiles of HIV-positive/AIDS patients. This paper examined the influence of nutrient supplementation on the anthropometric profile of HIV-positive/AIDS patients in black residential area of Bloemfontein, South Africa, so as to establish whether nutrient supplementation has any influence on the anthropometric indices or improve the quality of life of HIV-positive/AIDS patients.

Scientific evidence has revealed that several vitamins and minerals are critical for fighting HIV infection, because they are required by the immune system and major organs to attack infectious pathogens. Previous studies indicate that in the early period of HIV infection, weight gain or maintenance might be achieved through nutrient supplementation/good nutrition and has helped to reduce the consequences of wasting in people living with HIV/AIDS. Micronutrients have helped to strengthen the immune system and reduce the severity and impact of opportunistic infections in people living with HIV/AIDS. Data on supplementation in $\mathrm{HIV}$-infected persons in industrialised countries are widely available. However, this is often scarce in Africa; therefore a study to evaluate the role of nutritional supplementation in HIV-positive patients becomes necessary, especially in a developing country such as South Africa. Besides, a study concerned with nutritional supplementation of HIV-positive patients could be considered as very important due to the following: (1) HIV infection frequently results in nutritional deficiencies and growth failure. (2) Benefits from nutritional supplementation include not only the improved health and well-being of individuals but an 
improved chance of prolonged survival for those infected. (3) The knowledge acquired from this study would be vital in setting up nutrition intervention strategies for HIV-positive persons regarding various nutritional problems associated with HIV/AIDS.

\section{MATERIALS AND METHODS}

This is a purposive study that consisted of a baseline measurement and a monthly measurement that lasted from April to September 2003. Of the 35 patients recruited into the study at baseline, only 28 completed the study (2 dropped out while 5 died). The five respondents that died during the course of study were patients with severe immune deficiency and very poor nutritional status, compounded by secondary infections such as tuberculosis. An approval from the Ethics Committee of the Faculty of Health Sciences, University of the Free State (ETOVS 32/03) was obtained. The patients signed the consent form after they had been told the purpose and procedures of the study. Participants fulfilled the following criteria: male and female patients between 18 and 65 years of age and HIV positive; willing to undergo a pre-study physical examination; not on antiretroviral therapy; within the range of clinical acceptability in medical history and physical examination; CD4 ${ }^{+} \mathrm{T}$-cell count of $100-350$ cells $/ \mathrm{mm}^{3}$, able to comprehend; non-pregnant, non-diabetic, non-hypertensive or any other chronic disease and willing to sign a statement of informed consent. Only the patients that met the inclusion criteria participated in this study. For ethical reason, a placebo group was not included but results obtained during the screening period serve as internal control.

\section{Blood collection and Laboratory investigations} Blood samples were collected from each patient into sterile EDTA sample tubes. The CD4 ${ }^{+}$T-cell counts and $\mathrm{CD}^{+} \mathrm{T}$-cell counts were determined at baseline, monthly and at the end of the study. The $\mathrm{CD} 4{ }^{+} \mathrm{T}$-cell and $\mathrm{CD}^{+} \mathrm{T}$-cell counts were determined using flow cytometer (O'Brien et al., 1996).

\section{Anthropometric measurements}

At baseline and at the end of the study, the following anthropometric indices were determined and included body mass index (BMI) calculated from body weight and height in metres squared; waist-hip-ratio (WHR) calculated from waist circumference and hip circumference and skinfold thickness (to estimate percentage of body fat). For the anthropometric measurements, the subjects presented themselves in minimal clothing to allow measurements to be done quickly, accurately and efficiently. Two persons were involved with the measurement: the measurer and the recorder. This was to ensure accuracy of site location, correct sequence of measurement sites and accurate reading. The recorder repeats the value as it is being recorded in order to enable the measurer to do an immediate check. The measurement was done twice at each site on each subject and the average value was taken. Throughout the marking and measurement session, each subject stood relaxed, with arms comfortably by the side and with feet together. However, a few measurements required the subjects to place their feet apart. During the measuring period, the measurer was able to move around the subject easily and to manipulate the equipment. All anthropometric measurements were done according to standard procedures (Lee \& Nieman, 1993; 1996; Laquatra, 2004). The dietary intake of the patients in this study is reported in another paper that has been published in Medical Technology SA.

\section{Supplementation of patients}

Following the baseline measurement of the anthropometric indices, $\mathrm{CD} 4^{+} \mathrm{T}$-cell count, and $\mathrm{CD}^{+}{ }^{+} \mathrm{T}$-cell count the patients were given $7.5 \mathrm{ml}$ of the test supplement twice daily (between 7-9 am and 4-7 pm) for a period of six months. The research team and staff members of the South African Red Cross (home-based Care) in Bloemfontein handled the dosing and monitoring of the supplement intake on a daily basis. It was ensured that records of the receipt and administration of the study supplement were kept and that the supplement was not used for purposes other than as directed by the protocol. 


\section{Components of the supplement}

The contents of the supplement include the following extract of hypoxis (500 $\mathrm{mg}$ ), grape fruit seed extract (4 mg), sitosterol \& sitosterolin (28 $\mathrm{mg})$, beta-carotene $(1 \mathrm{mg})$, vitamin $\mathrm{E}(12.5 \mathrm{mg})$, vitamin $\mathrm{B}_{6}(7.5 \mathrm{mg})$, vitamin $\mathrm{B}_{1}(3.75 \mathrm{mg})$, vitamin $\quad \mathrm{B}_{2} \quad(10 \mathrm{mg})$, vitamin $\mathrm{B}_{12} \quad(3 \mu \mathrm{g})$, nicotinamide (5 mg), vitamin C (50 mg), olive green leaf extract (35 mg), folic acid (325 $\mu \mathrm{g})$ and natural anti-oxidant (biocydin) (52 mg).

\section{Follow-up Visits}

The patients were assessed on a monthly basis (the relationship between patients'clinical features and viral load has been published in Medical Technology SA) and there was no observable sideeffects reported resulting from taking the supplement indicating that the supplement was well tolerated. The $\mathrm{CD}^{+}{ }^{+}$-cell count and $\mathrm{CD}^{+}{ }^{+} \mathrm{T}$ cell count were repeated monthly while the anthropometric indices was repeated at the end of the study to determine any possible effect of the supplement on the anthropometric indices. Compliance with the regime was ensured by counting the supplements on a daily basis and by constantly reminding the patients of the need to follow the protocol. It was ensured that records of the receipt and administration of the study supplement were kept and that the supplement was not used for purposes other than as directed by the protocol.

\section{Statistical analyses}

The results for this study were analysed by an independent Biostatistician (as is the practice in the University) at the University of the Free State, Bloemfontein, South Africa, using SAS (1990). The results of the study are presented in mean, median, standard deviation and the significant difference put at $\mathrm{P}<0.05$ ).

\section{RESULTS}

The results of the baseline measurement of the 35 patients are indicated in Table 1. Thirty-two of the respondents $(94.1 \%)$ had a fat percentage below 20\% while 2 (5.9\%) had fat percentage above 25\%. One patient (female) was excluded from fat percentage because she exceeded the cutoff range for age. Of these 35 patients, 8 (22.9\%) had a BMI of less than $18.5 \mathrm{~kg} / \mathrm{m}^{2}, 24(68.6 \%)$ had a BMI range of $18.5-24.9 \mathrm{~kg} / \mathrm{m}^{2}$, while $3(8.6 \%)$ of the respondents had a BMI greater than $25 \mathrm{~kg} / \mathrm{m}^{2}$. Seven (87.5\%) of the respondents reported a WHR of less than 0.95 and 1 (12.5\%) of the respondents reported a WHR of greater than or equal to 0.95 for males. In the female group, 13 (48.1\%) of the respondents reported a WHR of less than 0.8 while $14(51.9 \%)$ reported a WHR of greater than or equal to 0.8 (table 1 ).

The results of the 28 patients at the end of the study are also indicated in Table 1 . The result showed that $26(96.3 \%)$ of the patients reported fat percentage below $20 \%$ while one had fat percentage above $25 \%$. Of the 28 patients, 7 (25\%) had a BMI of less than $18.5 \mathrm{~kg} / \mathrm{m}^{2}, 19$ $(67.9 \%)$ had a BMI within the range of 18.5 $\mathrm{kg} / \mathrm{m}^{2}-24.9 \mathrm{~kg} / \mathrm{m}^{2}$, and $2(7.1 \%)$ had a BMI greater than or equal to $25 \mathrm{~kg} / \mathrm{m}^{2}$. Seven $(87.5 \%)$ of the patients had a WHR of less than 0.95 and 1 $(12.5 \%)$ had a WHR of greater than or equal to 0.95 . Ten (50\%) had a WHR of less than 0.8 and $10(50 \%)$ had a WHR greater than or equal to 0.8 for female patients (table 1).

The mean, median, standard deviation, 25 percentile and 75 percentile of the anthropometric indices are presented in Tables 2. The median fat percentage of $19.2 \%$ at baseline was not significantly lower than the normal range $(20 \leq 25 \%)$. The fat percentage had not decreased significantly $(\mathrm{P}>0.05)$ by the end of nutrient supplementation. The median BMI of the population (inclusive of male and female adults) fell within the accepted/normal range of $20 \mathrm{~kg} / \mathrm{m}^{2}$ and less than $25 \mathrm{~kg} / \mathrm{m}^{2}$. At baseline, the median BMI was $20.4 \mathrm{~kg} / \mathrm{m}^{2}$ (within a reference range). It showed a slight trend towards an insignificant increase to $20.7 \mathrm{~kg} / \mathrm{m}^{2} \quad(\mathrm{P}>0.05)$ following supplementation. The median WHR of 0.81 showed normal waist circumference of the study population. The median WHR seem to be maintained up to the end of nutrient supplementation. The median LBM increased insignificantly ( $\mathrm{P}>0.05)$ from $45.5 \mathrm{~kg}$ at baseline to $46.1 \mathrm{~kg}$ by the end of nutrient supplementation. 
Table 1:

The frequency and percentage of body fat, BMI and WHR of HIV-positive patients at baseline and at the end of study

\begin{tabular}{|c|c|c|}
\hline Anthropometric profile & Baseline visit $(n=35)$ & Final visit $(n=28)$ \\
\hline & Freq \& percentage & Freq \& percentage \\
\hline \multicolumn{3}{|l|}{ Fat \%* } \\
\hline$<\mathbf{2 0}$ & 32 (94.1\%)* & 26 (96.3\%)* \\
\hline $20 \leq 25$ & $0(0 \%)$ & $0(0 \%)$ \\
\hline$>2 \overline{5}$ & $2(5.9 \%)$ & $1(3.7 \%)$ \\
\hline \multicolumn{3}{|l|}{ BMI $\left(\mathrm{kg} / \mathrm{m}^{2}\right)$} \\
\hline$<18.5$ & $8(22.9 \%)$ & $7(25 \%)$ \\
\hline $18.5-24.9$ & $24(68.6 \%)$ & $19(67.9 \%)$ \\
\hline$\geq 25$ & $3(8.6 \%)$ & $2(7.1 \%)$ \\
\hline \multicolumn{3}{|l|}{ WHR } \\
\hline$<0.95$ (male) & $7(87.5 \%)$ & 7 (87.5\%) \\
\hline$\geq 0.95$ (male) & $1(12.5 \%)$ & $1(12.5 \%)$ \\
\hline$<0.8$ (female) & $13(48.1 \%)$ & $10(50 \%)$ \\
\hline$\geq 0.8$ (female) & $14(51.9 \%)$ & $10(50 \%)$ \\
\hline
\end{tabular}

*One patient (female) was excluded from fat percentage because she exceeded the cut-off range for age.

Table 2:

Anthropometric profiles of HIV-positive/AIDS patients at baseline and end of study

\begin{tabular}{|c|c|c|c|c|c|c|c|c|c|c|}
\hline \multirow{2}{*}{$\begin{array}{l}\text { Anthropometric } \\
\text { Indices }\end{array}$} & \multicolumn{5}{|c|}{ Before nutrient supplementation $(n=35)$} & \multicolumn{5}{|c|}{ After nutrient supplementation $(n=28)$} \\
\hline & Mean & SD & Median & $\begin{array}{l}25 \\
\text { percentile }\end{array}$ & $\begin{array}{l}75 \\
\text { percentile }\end{array}$ & Mean & SD & Median & $\begin{array}{l}25 \\
\text { \%centile }\end{array}$ & $\begin{array}{l}75 \\
\text { \%centile }\end{array}$ \\
\hline Weight (kg) & 55.2 & 8.2 & 57.0 & 49.0 & 60.0 & 55.7 & 7.4 & 56.0 & 50 & 60.0 \\
\hline Height (m) & 1.6 & 0.1 & 1.6 & 1.55 & 1.7 & 1.6 & 0.1 & 1.6 & 1.6 & 1.7 \\
\hline \% fat & 17.8 & 4.7 & 19.2 & 13.6 & 20.3 & 17.2 & 4.9 & 17.9 & 12.6 & 20.7 \\
\hline BMI (kg/M²) & 21.2 & 3.3 & 20.4 & 18.7 & 23.2 & 21.2 & 3.4 & 20.7 & 18.8 & 23.2 \\
\hline WHR & 0.8 & 0.1 & 0.8 & 0.8 & 0.8 & 0.8 & 0.1 & 0.81 & 0.8 & 0.9 \\
\hline LBM (kg) & 45.2 & 6.2 & 45.5 & 40.4 & 49.3 & 45.7 & 5.4 & 46.1 & 41.3 & 49.6 \\
\hline
\end{tabular}

Table 3:

Correlation between different anthropometric profiles and $\mathrm{CD} 44^{+} \mathrm{T}$-cell count at baseline and final visit

\begin{tabular}{|c|c|c|c|c|c|}
\hline \multicolumn{2}{|c|}{ Correlation Between } & \multicolumn{2}{|c|}{ Baseline visit (n=35) } & \multicolumn{2}{|c|}{ Final visit $(n=28)$} \\
\hline Variable 1 & Variable 2 & $\mathbf{R}$ & p-value & $\mathbf{R}$ & p-value \\
\hline \multirow[t]{4}{*}{ LBM } & $\%$ fat & 0.036 & 0.84 & -0.08 & 0.7 \\
\hline & BMI & 0.39 & $0.02 *$ & 0.14 & 0.5 \\
\hline & WHR & -0.13 & 0.45 & -0.07 & 0.7 \\
\hline & $\begin{array}{l}\mathrm{CD} 4^{+} \mathrm{T} \text {-cell } \\
\text { count }\end{array}$ & 0.25 & 0.2 & 0.08 & 0.6 \\
\hline \multirow[t]{3}{*}{$\%$ fat } & BMI & 0.74 & $<0.0001^{* * *}$ & 0.81 & $<0.0001^{* * *}$ \\
\hline & WHR & -0.38 & $0.02 *$ & -0.4 & $0.05^{*}$ \\
\hline & $\begin{array}{l}\mathrm{CD} 4^{+} \mathrm{T} \text {-cell } \\
\text { count }\end{array}$ & 0.06 & 0.74 & 0.006 & 0.97 \\
\hline \multirow[t]{2}{*}{ BMI } & WHR & -0.45 & $0.006^{*}$ & -0.31 & 0.1 \\
\hline & $\begin{array}{l}\mathrm{CD} 4^{+} \mathrm{T} \text {-cell } \\
\text { count }\end{array}$ & 0.2 & 0.32 & 0.02 & 0.9 \\
\hline WHR & $\begin{array}{l}\text { CD4 }{ }^{+} \text {T-cell } \\
\text { count }\end{array}$ & -0.07 & 0.7 & 0.05 & 0.7 \\
\hline
\end{tabular}

NS (not significant): $P>0.05, r=$ correlation; ${ }^{*} P<0.05 ; * * P<0.01$; $* * * P<0.001$. 
African Journal of Biomedical Research 2008 (Vol. 11) / Oguntibeju, van den Heever \& Van Schalkwyk

Table 4:

T-lympocytes subsets of HIV-positive/AIDS patients at baseline and end of study

\begin{tabular}{|c|c|c|c|c|c|c|c|}
\hline \multirow[t]{2}{*}{ Variables } & \multicolumn{3}{|c|}{ Baseline visit $n=35$} & \multicolumn{3}{|c|}{ Final visit $n=28$} & \multirow[t]{2}{*}{ P-value } \\
\hline & Mean & SD & Median & Mean & SD & Median & \\
\hline $\begin{array}{l}\text { Total Tcell } \\
\text { count } / \mathrm{mm}^{3}\end{array}$ & 1615 & 736.3 & 1543 & 1495.7 & 758.9 & 1400 & 0.07 \\
\hline $\begin{array}{l}\mathrm{CD}^{+}{ }^{\top} \mathrm{T} \text {-cell } \\
\text { count } / \mathrm{mm}^{3}\end{array}$ & 203.9 & 83.5 & 176 & 188.2 & 96.9 & 164 & $<0.03 *$ \\
\hline $\begin{array}{l}\mathrm{CD8}^{+} \mathrm{T} \text {-cell } \\
\text { count } / \mathrm{mm}^{3}\end{array}$ & 1407.2 & 672.2 & 1254 & 1267.1 & 686.9 & 1228 & 0.09 \\
\hline
\end{tabular}

SD (standard deviation)

The P-value tested the difference between the immunological parameters at baseline and final visit

$* \mathrm{P}<0.05$. Parameters with the same superscript showed statistical difference.

The correlation between anthropometric indices and $\mathrm{CD} 4^{+} \mathrm{T}$-cell count at baseline and at the end of nutrient supplementation were determined and are presented and shown in table 3. The Tlymphocytes subsets of the patients both at baseline and following the end of supplementation are presented in table 4 .

\section{Baseline measurement}

This study did not indicate a correlation between the LBM and percentage of body fat $(\mathrm{P}>0.05)$, the WHR $(\mathrm{P}>0.05)$ and the $\mathrm{CD} 4^{+} \mathrm{T}$-cell count $(\mathrm{P}>0.05)$ (table 3 ). However, the results showed a positive correlation between the LBM and the BMI $(\mathrm{P}<0.05)$. The fat percentage showed a positive correlation with the BMI $(\mathrm{P}<0.0001)$ but a negative correlation with the WHR $(\mathrm{P}<0.05)$. There was no correlation between the fat percentage and the $\mathrm{CD} 4{ }^{+} \mathrm{T}$-cell count $(\mathrm{P}>0.05)$. The BMI indicated a correlation with the WHR $(\mathrm{P}<0.05)$. No correlation was observed between the BMI and the $\mathrm{CD} 4{ }^{+} \mathrm{T}$-cell count $(\mathrm{P}>0.05)$. There was no correlation between the WHR and the $\mathrm{CD} 4^{+} \mathrm{T}$-cell count $(\mathrm{P}>0.05)$, table 3 .

\section{Final measurement}

In the final measurement, there was no correlation between the LBM and the fat percentage, the BMI, the WHR and the $\mathrm{CD} 4{ }^{+} \mathrm{T}$-cell count (table 3 ). The fat percentage correlated with the BMI $(\mathrm{P}<0.0001)$ and negatively correlated with the WHR $(\mathrm{P}<0.05)$.

\section{DISCUSSION}

Studies in developed countries have reported the impact of HIV infection on nutritional status at different stages of the infection [Kotler et al., 1989; Ott et al., 1993). It is reported that malnutrition is a general problem among HIVinfected patients, but it has become much less frequent among HIV-infected persons in developed countries, mainly due to the provision of highly active antiretroviral therapy (HAART) and nutritional interventions (Carbonnel, 1998). There have been increasing recommendations for supplementation to form part of the general nutritional interventions to correct some of the nutritional complications associated with HIV infection especially in Africa where people cannot afford highly active antiretroviral drugs. The goals of nutritional assessment and intervention are aimed at improving nutritional status, prolonging survival and enhancing quality of life.

In this study, anthropometric indicators of HIV-positive/AIDS patients were determined at baseline and the end of the nutritional supplementation so as to be able to observe the potential influence of the nutritional supplement on the anthropometric indicators. The body weight of the patients had not declined significantly by the end of nutrient supplementation. This finding agrees with the trend reported by Parisien et al (1993) for the body weight of HIV-positive/AIDS patients. Studies 
have shown that weight loss and decrease in body weight have been indicated as signs of a deterioration of nutritional status in HIVpositive/AIDS patients (Macallan, 1999; Dannhauser et al., 1999; Myers, 1997). In a study, McCorkindale (1990) reported that seven patients at an advanced stage of HIV infection did not show a significant decline in body weight or fat percentage. His patients were on an antiretroviral drug (AZT) for five months. This trend of change underscores the different but yet unclear mechanisms involved in the wasting process in HIV infection. However, in this study although the patients were not on any antiretroviral therapy, the supplement did not demonstrate an observable effect on the body weight. Other factors may explain why the expected weight gain did not occur. Firstly, patients with HIV infection/AIDS may be hypermetabolic, therefore the anticipated weight gain is an overestimation because energy needs and expected weight gain are calculated on the basis of normal metabolic states (Melchoir et al., 1991). Secondly, HIV infection disrupts the normal lipid and protein metabolism and causes nutrients to be used inefficiently and wasted (Hellerstein et al., 1993).

According to Wiley \& Samuel (1989; Serwadda et al.(1985) and O'Sullivan et al.(1985), weight loss and/or a decrease in body weight is a prominent feature of HIV infection/AIDS. O'Sullivan et al.[1985) noted that of the 50 HIVpositive/AIDS patients admitted to hospital, despite the fact that their pre-illness weights were higher than normal body weights, 59\% of the patients were classified as moderately depleted and $62 \%$ had lost $>10$ of their pre-illness weight. In this study, the pre-illness weights of the patients were not determined because patients were unable to recall their pre-illness weights. The reduction in weight of the patients by the end of nutrient supplementation in this study was not significant. If Serwadda's et al. (1985) report did reflect the process of nutritional depletion taking place in HIV-positive/AIDS patients as reflected in the reduction of weight, then we are tempted to believe that the supplement probably has a positive but non visible effect on the weight of the patients. In other words, since the patients were not on antiretroviral therapy, weight reduction or reduction in other anthropometric indicators should have been higher than observed. Likewise, nutritional deterioration of the patients should have been clearly demonstrated in the clinical conditions of the patients. At the same time we are cautious with such interpretation in the presence of limitations such as sample size and lack of a placebo group that faced this study. Clinical conditions such as tuberculosis and other bacterial and fungal infections were treated; therefore treatment could have contributed in reducing the degree of wasting. The clinical and physical conditions of the patients improved with time following supplementation and/or treatment.

The percentage of body fat determined anthropometrically at baseline had not changed significantly by the end of the study (table 1 ). This result is similar to that reported by Dannhauser et al. (1999) At baseline $94.1 \%$ of the population reported fat percentage below the $18.5 \%$, while $96.3 \%$ of the population (table 1) reported fat percentage by the end of the study, thus the fat percentage showed no significant depletion. This pattern of depletion resembles a stressed or injured state rather than starvation or semi-starvation that is associated with nitrogen saving and increased fat utilization. The result showed a positive correlation between the BMI and fat percentage while the latter did not show a significant correlation with the $\mathrm{CD}^{+}{ }^{+} \mathrm{T}$-cell count, but a negative correlation with the viral load. Generally, the BMI, LBM and WHR were maintained over the course of the time in this study.

The fact that in this population of HIVpositive/AIDS patients, the LBM was relatively preserved possibly suggests that no major aggressive factor was obviously present in all the patients. One previous study (MacClave \& Mittoraj, 1992) identified an aggressive factor (Tuberculosis-TB) that significantly contributed to the severity of malnutrition. TB was present in 6 of our patients (17.1\%) at baseline but the patients with TB were treated during the course of the study. It is presumed that the treatment reduced the aggressive impact of TB on the lean body mass. It is possible that the wasting process was 
curtailed, probably to a certain degree in the presence of the treatment with the supplement playing a secondary role. It is believed that the wasting process would have been more aggressive in the absence of the treatment and supplement (probably more of the effect of the treatment with anti-TB) because during active phases of infection, people with HIV/AIDS lose LBM rapidly (Gorbach \& Knox, 1992).

The results obtained in this study for the BMI and LBM are similar to those reported by Kennedy et al (1996) following nutrient supplementation. The BMI significantly correlated with the LBM. The LBM showed no correlation with the $\mathrm{CD} 4^{+} \mathrm{T}$ cell count.

The BMI and fat percentage were lower in patients with $\mathrm{CD} 4{ }^{+} \mathrm{T}$-cell counts $<200$ cells $\mathrm{mm} /{ }^{3}$ than in those with CD4 $4^{+} \mathrm{T}$-cell counts $>200$ cells $\mathrm{mm} /{ }^{3}$. This is understood and expected in patients with immuno-deficient diseases such as AIDS, especially when the patients are not on antiretroviral therapy. This finding is similar to that reported by Castetbon et al (Kennedy et al., 2001) and (Dannhauser et al., 1999). It has been shown that a decrease in the lean body mass is related to the decrease in body cell mass (Niyongabo et al., 1997) and that body cell mass depletion is out of proportion to losses of body weight for fat (MacClave \& Mittoraj, 1992; Castetbon et al., 1997; Kotler, 1992). It has also been shown that death from wasting in AIDS is related to the body cell mass depletion rather than to the specific underlying cause of the wasting (Kotler et al., 1989). As previously demonstrated by anthropometry, decline in weight and BMI have been associated with a decline in percentage of body fat.

Although a greater percentage of patients (68.6\%) had a BMI within a range of 18.5-24.9 $\mathrm{kg} / \mathrm{m}^{2}, 22.9 \%$ of the patients had a BMI of less than $18.5 \mathrm{~kg} / \mathrm{m}^{2}$ (table 1), therefore for those patients with a lower BMI, reduced body fat may have contributed. It is expected that as the HIV infection/disease progresses, wasting may become more pronounced, which in most cases is reflected in the amount of fat loss or lean body mass. In this study, instead of the wasting continuing significantly, as would have been indicated by a significant decline in the anthropometric indicators, it was relatively curtailed. It is possible that certain factors such as malabsorption, short duration, and drug-nutrient interactions contributed to the non-significant effect of the supplement on the anthropometric indicators (Kotler, 1997; Pronsky et al., 2001) but needs further investigation with large sample size to clarify.

\section{Conclusion}

In a population in which antiretroviral therapy is not readily available or accessible, the findings that nutrient supplementation more or less maintained the BMI or LBM or has the potential of maintaining the BMI or LBM, shows the contributing role of nutritional supplement on the quality of life and the general well-being of HIVpositive patients. However, nutritional supplement is not a substitute but complementary to antiretroviral therapy. Antiretroviral therapy is still by far a better approach for treating HIV/AIDS patients and African government should be encouraged to provide antiretroviral therapy to their HIV-infected citizens.

\section{Application}

Nutritional abnormalities are frequent and a characteristic feature of infection with the human immunodeficiency virus (HIV), and they represent a major determinant of survival. Nutritional status may have an impact at all stages of HIV infection: from the initial acquisition of infection, clinical manifestations, progression of HIV infection/disease and palliation of advanced disease. Nutritional care of HIV-infected patients should therefore begin at the time of diagnosis so as to assess baseline nutritional status/anthropometric indices and to provide dietary counselling/guidelines. Dietary guidelines should include the recommendation of a nutrient supplement containing anti-inflammatory agents and antioxidants. Close monitoring of nutritional status and clinical status is essential in identifying nutritional problems or need for nutrient supplementation. 


\section{Recommendations}

The following recommendations are made in the light of the results obtained from this study:

- Nutritional intervention should begin early in patients with HIV infection and AIDS.

- Nutritional supplementation should form an important aspect of the clinical management of HIV-positive/AIDS patients as it may help to strengthen the immune system, replace lost vitamins/minerals and reduce the severity of impact of opportunistic infections in people living with HIV/AIDS.

- Standardised evaluation of nutritional status should be done regularly.

- In future, supplementation-based research studies should be directed towards patients with HIV infection and AIDS, with secondary infections and with or without wasting.

- Confirmation of the results of our study is required using the same nutrient supplement and patient-entry criteria, and a control group but for a longer period, for example one year.

\section{Acknowledgement}

The Central university of Technology, Free State provided the main funding for the study. The financial assistance from the HIV Council of the Free State government and National Research Foundation of South Africa is acknowledged. Thanks to Pathcare laboratory for assisting with laboratory analyses, Pro Nutro supplied the porridge to patients and Bermins provided the supplement

\section{REFERENCES}

Babamento G \& Kotler DP (1997): Malnutrition in HIV infection. Gastroenterol Clin North Am 26: 393-415.

Carbonnel F, Maslo C, Beaugerie L, Carat F, Wirbel E, Aussel C et al. (1998): Effect of indinavir on HIV-related wasting. AIDS 12: 1777-1784.

Castetbon K, Kadio A, Bondurand A, Boka Yao A \& Barouan C (1997): Nutritional status and dietary intakes in human immunodeficiency virus (HIV)-infected outpatients in Abidjan, Cote d'Ivoire, 1995. European J Clin Nutr 51: 81-86.

Chlebowski RT (1985): Significance of altered nutritional status in acquired immune deficiency syndrome. Nutr Cancer 7: 85-91.

Cimoch P (1997): Nutritional health. Prevention and treatment of HIV-associated malnutrition: A case manager's guide. International Association of Physicians in AIDS Care 1997. www.iapac.org/clinmgt/nutrition/caseguide.html.

Dannhauser A, Van Staden AM, Van der Ryst E, Nel M, Marais N, Erasmus E et al. (1999) Nutritional status of HIV-1 sero-positive patients in the Free State Province of South Africa: Anthropometric and dietary profile. European J Clin Nutr 53: 165-173.

Dwyer D (1998). Unproven Nutrition Therapies for AIDS: What is the Evidence? Nutrition Today 13: 25-33.

Fawzi WW \& Hunter DJ (1998): Vitamins in HIV disease progression and vertical transmission. Epi 9: 457-466.

Friis H \& Michaelsen KF (1998): Micronutrients in HIV infection: a review. European J Clin Nutr 52: 157-163.

Gorbach S \& Knox T (1992): Weight loss and human immunodeficiency virus infection: cachexia versus malnutrition. Infect Dis Clin Pract 1: 224-229. Grunfeld C \& Feingold K (1992): Metabolic disturbances and wasting in the acquired immunodeficiency syndrome. Symposium: nutritional immunomodulation and AIDS. J Nutr 122: 723-727.

Hellerstein MK, Grunfeld C, Wu K, Christiansen M, Kaempfers S, Kletke C et al. (1993): Increased de novo hepatic lipogenesis in human immunodeficiency virus infection. J Clin Endocrinol Metab 76:559-565.

Herbert V (1973): The five possible causes of all nutrient deficiency: illustrated by deficiencies of vitamin $\mathrm{B}_{12}$ and folic acid. Am J Clin Nutr 26: 77-86. Kennedy OC, Coutsoudis A, Kuhn L (2001): Effects of vitamin A supplementation during pregnancy and early lactation on body weight of South African HIV-infected women. J Health Popl \& Nutr 19 (3): 167-176.

Kotler DP (1992). Nutritional effects and support in the patient with acquired immunodeficiency syndrome. J Nutr 122: 723-727.

Kotler DP (1997): Management of nutritional alterations and issues concerning quality of life. J Acquir Defic Syndr \& Hum Retrovirol 16 (1): S30S35.

Kotler DP, Engelson ES, Thea DM, Wang J, Pierson RN, Saint-Louis M et al. (1996): Different body composition changes in men and women with AIDS. X1 International Conference on AIDS. 8-11 
July, Vancouver, Canada.

Kotler DP, Tierney AR, Wang J \& Pierson RN (1989): Magnitude of body-cell-mass depletion and the timing of death from wasting in AIDS. Am J Clin Nutr 50:444-447.

Laquatra I (2004): Nutrition for weight management. In: Mahan LK, \& Escott-Stump S, (ed). Krause's Food Nutrition \& Diet Therapy. $11^{\text {th }}$ Edition, Philadelphia: WB. Saunders Co: pp: 488493

Lee RD \& Nieman DC (1993): Anthropometry. In: Nutrition Assessment, ed. RD Lee \& DC Nieman. Oxford: WCB Brown \& Benchmark pp: 121-165.

Lee RD \& Nieman DC (1996): Nutritional Assessment. $2^{\text {nd }}$ Ed. McGraw Hill comp pp: 119126.

Macallan DC (1999): Dietary intake and weight loss patterns in HIV infection. In: Miller TI \& Gorbarch SL, eds. Nutritional aspects of HIV infection. New York: Oxford University Press pp: 23-34.

MacClave S, Mittoraj MD, Thielmeier KA \& Greenburg RA (1992): Differentiating subtypes (hypoalbuminemic vs marasmic) of protein calorie malnutrition: incidence and clinical significance in a University setting. J Pop Epi Nutr 16: 337-342.

McCorkindale C, Dybevik K, Coulstom AM \& Sucher KP (1990): Nutritional status of HIVinfected patients during early disease stages. J Am Diet Assoc 90: 1236-1241.

Melchoir JC, Salmon D, Rigaud D, Leport C, Bouvet E, Detruchis P (1991): Resting energy expenditure is increased in stable malnourished HIVinfected patients. Am J Clin Nutr 53: 437-441.

Myers C (1997):Vitamin/mineral supplementation \& HIV/AIDS. Nutrition Series 7: 1-3.

Niyongabo T, Bouchaud O, Henzel D, Melchior JC, Samb B Daza, MC et al (1997): Nutritional status of HIV-1 sero-positive subjects in an AIDS clinic in Paris. Eur J Clin Nutr 51: 637-640.

Niyongabo T, Henzel $D$, Ndayishimyie JM, Melchoir JC, Ndayiragije A et al. (1999): nutritional status of adult inpatients in Bujumbura, Burundi (impact of HIV infection). European J Nutr 53: 579-582.

O’Brien WA, Hartigan PM \& Martin D (1996): Changes in plasma HIV-RNA and CD4 lymphocyte counts and the risk of progression to AIDS. Veteran Affairs Cooperative Study Group on AIDS. New Engl J Med 334: 426-431.

O'Sullivan P, Linke RA, Dalton S (1985):
Evalaution of body weight and nutritional status among AIDS patients. J Am Diet Assoc 85:14831484.

Oguntibeju OO, Veldman D \& Van Schalkwyk F (2003): Nutritional status of people living with HIV/AIDS: The situation in Africa: a review. J Biomed \& Lab Sci 15 (3): 63-67.

Oguntibeju OO, WMJ van den Heever \& FE van Schakwyk (2005a): An analysis of baseline dietary intake of HIV-positive/AIDS patients. Medical Technology SA 19 (2): 3-9.

Oguntibeju OO, WMJ van den Heever \& FE van Schakwyk (2005b): The potential effect of a nutrition supplement on the health status of HIVpositive/AIDS patients. Medical Technology SA 18 (2): 5-8.

Ott M, Lembeke B, Fischer H, Jager R, Polat H, Geier H (1993): Early changes of body composition in human immunodeficiency virus-infected patients: tetrapolar body impedance analysis indicates significant malnutrition. Am J Clin Nutr 57: 15-19.

Parisien C, Gelinas MD \& Cossette M (1993): Comparison of anthropometric measures of men with HIV: asymptomatic, symptomatic and AIDS. J Am Diet Assoc 93: 1404-1408.

Piwoz EG \& Preble EA (2000): HIV/AIDS and nutrition: a review of the literature and recommendations for nutritional care and support in sub-Saharan Africa. A Technical Report, pp: 1-4.

Pronsky ZM, Meyer SA, Fields-Gardner C (2001): HIV Medications and Food Interactions. Second Edition. Food-Medication Interactions Publisher: Birchrunville, USA pp: 20-26

Raiten DJ (1990): Nutrition and HIV infection: a review and evaluation of the exact knowledge on the relationship between significant malnutrition and HIV infection. Nutr Clin Pract 6: 1S-94S.

SAS (1990): SAS procedures guide, version $3^{\text {rd }} \mathrm{ed}$, Cary NC: SAS Institute Inc pp: 705-991.

Serwadda D, Mugerwa RD, Sewankambo NK, Lwegaba A, Carswell JW, Kirya GB et al. (1985):

Slim disease: a new disease in Uganda and its association with HTLV-111 infection. Lancet 2: 849852.

Wiley JA, Samuel MC (1989): Prevalence of HIV infection in the USA. AIDS 3 (Suppl 1): S71-78.

Woznicki D \& D'Alessandro G (1997): Nutrition against AIDS. Am Council on Science \& Health 9 (2): 1-4. 